\title{
A Feminist Approach to Analyze Virginia's Death
}

\author{
Rongqiong Guo \\ Xi'an Peihua University, Xi'an, Shanxi, 710100 China. \\ 263168489@qq.com
}

Keywords: Virginia's Death, Lost Image, Feminist Criticism.

\begin{abstract}
Michal Cunningham (1952-) is one of the most famous and popular American writers nowadays. His work The Hours, published in 1998, has earned a resounding success and awarded PEN/Faulkner Award and Pulitzer Prize. The Hours established Cunningham as a major force in American writing, the research about The Hours and its author Michal Cunningham at home started about 2002 when the Chinese version had been published in China. The book concerns three generations of women lived about 70 years' time span and affected by a Virginia Woolf novel. Virginia Woolf herself writing Mrs. Dalloway in 1923 and struggling with her own mental illness. With the development of the feminist movement and female liberation many feminist critics interpret the Virginia Woolf's death in The Hours from the perspective of feminism, and other different aspects. By analyzing the root of Virginia's death, this paper designs to explore the feminist in Virginia's death. Therefore, this paper has the positive meaning for the female liberation which offers a new possibility for feminist study.
\end{abstract}

\section{Introduction}

Feminist literary criticism knows as the critical analysis of literary works based on the feminist perspective. In other words, feminist literary criticism is a kind of literary criticism on the basis of feminist theory or the politics of feminism more precisely. In particular, it also can be explained as using ideological discourses and feminist rules to study language, structure and being of literature. "This school of thought seeks to describe and analyze the ways in which literature portrays the narrative of male domination in regard to female bodies by exploring the economic, social, political, and psychological forces embedded within literature."

(https://owl.english.purdue.edu/owl/resource/722/11/)

In the male-dominated society, women as the other and the second sex have to suffer their fates of being dominated by men, Virginia being a housewife and treated in difference in every sectors of society. Virginia suffered from the male-dominated society for her imprisoned by the male-dominators and live too insignificant to lose themselves.

Virginia, a talented female who devotes her life to writing and has feminist consciousness, still has to suffer the confinement from her husband and her doctor in the name of doing out of love and for her betterment. She feels so suffocated that she could no longer bear this confinement anymore and commit a suicide to pursue her freedom. Due to the awareness of feminine awakening consciousness, Virginia, refuse to be the other willingly and commit themselves to find their real freedom respectively. Virginia cannot bear the mental illness and imprisonment of her husband any longer and she commit a suicide by drowning herself in a river nearby to gain her forever freedom.

\section{Virginia's Death}

\subsection{Revolt of the Patriarchy.}

In the prologue of The Hours, the writer describes the process of Virginia's suicide. She leaves two letters one for her husband Lenard and another for her sister Vanessa, flees from the house and steps to the center of river. She is desperately to die and feels ease and still when she is dying. She writes to Lenard that she cannot read and write properly and she is doing what seems the best thing to do. 
The steadfast way of fighting against the patriarchy for her is writing. However, she is going mad again and feels she shan't recover in that the doctor and guardian are all males who never really care about what she truly wants. That is to say, as the other, she struggles for her freedom in various ways but all didn't work and she is tired of fighting and suffering and she has no choice but to die. She regards the death is the final success of achieving real freedom.

First, she is a rebel against her husband. As the other, Virginia spares no efforts to fight for her own freedom. She tries a lot for sake of freedom of living and writing. All her trying to do is to make her own judgments and choices for her own good by herself. However, she is watched by her husband and compelled by her doctor in the small-town Richmond where she has no wish to live in. Then she doesn't listen to Lenard's arrangement for her, lying and smoking.

"Have you had breakfast?" he asks.

"Yes."

"Liar.” "I'm having coffee with cream for breakfast. It's enough.”

"It's far from enough. I'm going to have Nelly bring you a bun and some fruit."

"If you send Nelly in to interrupt me I won't be responsible for my actions."

"You must eat," he says. "It doesn't have to be much."

"I’ll eat later. I’m going to work now.” (Michael Cunningham, 1999: 32-33).

As we can see that Virginia is very impatient and sick with Lenard's constraint and insists on disobeying his orders from their dialogue. Unfortunately, her rebellion is so trivial and weak that it makes no difference and changes nothing in her life, that is to say, her revolt is still under control by the males and in the sphere of patriarchy, thus this kind of fighting will never bring her real freedom.

\subsection{Pursuit of the Freedom.}

She attempts to pursue her freedom by writing. Virginia is a lucky woman who has a room to write and hopes that she can avoid tedious life by indulging herself in books. However, her independent place has always been interrupted by servant who needs the instruction of cooking meals from her. She could never escape her role of woman who should be responsible for taking care of family routine. She anchors her hope on the books but writing for her seems that something naturally happens to her but something under her control. Due to the doctor's advice, her right of writing has also been violated. She has to sleep, eat and relax on time neglecting her own will. What's worse, her writing always has been stopped by her headache and mental illness. Therefore, she is more eager to accomplish her writing as much as she can for fearing of her mental disorder haunted her again. During her writing, she keeps thinking about the final fate of her heroine, which implies her suicide latter. Virginia is incredibly sensitive to the world that she realizes only death is the real liberation.

For Virginia, various attempts have been done and she still lives in a suffocated life, there is no way out but to die. Under the patriarchy, as the second sex, Virginia can never get the real help from the males and fails to get the understanding and support from females especially her beloved sister Vanessa. She is desperate at the failure of fighting and pursuing. Then at one morning, she leaves two notes, dresses warmly, hurries from her house and walks toward the nearby river. Without hesitation, she selects one stone and put it into her pocket and walks in the river. "Then, is the last moment of true perception," "for a moment, still, it seems like nothing" (Michael Cunningham, 1999: 5). As she lays dying, she finds the inner peace and true happiness and freedom. In some extent, Virginia may truly find her paradise of being free however, death itself is no more than a tragedy no matter what form it is. Thereupon, her extreme way of pursuing the freedom makes her more pathetic and miserable. Virginia drowns herself to death and get free forever. But in fact, death itself is a tragedy and it means the termination of fighting.

To interpret Virginia's Death of the novel is another way of studying The Hours. Thanks to the affection about female living state and the reflection of the death in The Hours, this novel not only obtains outstanding artistic achievement but also glows with strong enchantment. 


\section{Feminist Consciousness in Virginia's Death}

Feminist literary criticism knows as the critical analysis of literary works based on the feminist perspective. In other words, feminist literary criticism is a kind of literary criticism on the basis of feminist theory or the politics of feminism more precisely. Patriarchy is one of the key terms in feminist literary criticism. Feminists consider that it is a social system in which men are the principal authority figures. Thus, the coexistence of revolting and compromising make them lose image during their way of resistance and pursuit.

For Virginia Woolf herself, creation plays an important role in her life not only because writing is a way of expressing her emotions, ideas and exploring the world she lives in, but also it is a harbor for her escaping her insanity. "It is more than the sum of her intellect and her emotions, more than the sum of her experiences, through it runs like veins of brilliant metal through all three. It is an inner faculty that recognizes the animating mysterious of the world because it is made of the same substance, and when she is very fortunate she is able to write directly through that faculty. Writing in that state is the most profound satisfaction she knows” (Michael Cunningham, 1999: 35)

She has the consciousness that she has to play others social roles but not only to be a writer. She has to obey Lenard's order as a wife, to make contact with her maid Nelly as a housewife and so on. All these social roles like confinement to her. She flees to the train station but she has no courage to escape her duties and roles. When she is way back to home with Lenard, she keeps thinking "On the other side is the train. On the other side is London, and all London implies about freedom, about kisses, about the possibilities of art and the sly dark glitter of madness.” (Michael Cunningham, 1999: 172) This dilemma between freedom in London and confinement in Richmond drives her misery and crazy.

\section{Conclusion}

All in all, a pioneer of modern feminism, never really achieve her true happiness and freedom for her halfway feminist consciousness and the ingrained patriarchy system. Although she hasn't change her situations and their role of being the other completely and successfully, the courage and efforts she has made to fight against the patriarchy, fight for her liberation could never be forgotten, which inspire the followers to keep struggling. We can learn the lesson of their failure, look ahead and continue to accomplish our goal of female's liberation.

\section{References}

[1]. Cunningham, Michael. The Hours. London: Harper perennial, 2006.

[2]. Pyyhtinen,Olli.Simmel and "the social”. NewYork:Palgrave Macmillan,2010.

[3]. De Beauvoir, Simone. The Second Sex. [M] New York: Alfred A. Knot, 1986.

[4]. Kant, I. 1785, Groundwork of the Metaphysic of Morals, translated and analyzed by H.J. Paton, New York: Harper \& Row, 1948.

[5]. Hamm, Maggie. The Dictionary of Feminist Theory. 2nd Ed. New York: Prentice Hall and Harvester Wheat sheaf, 1995.

[6]. Harding, Sandra. Feminism and Methodology. Bloomington: Indiana University Press, 1987.

[7]. Gamble, Sarah, Ed. The Rutledge Companion to Feminism and Post feminism. New York: Rutledge, 2001.

[8]. Millet, Kate. Sexual Politics. [M] Garden City: Doubleday, 1970.

[9]. Lodge, David. After Bhakti: Essays on Fiction and Criticism. London: Rutledge, 1990. 